Article

\title{
Addressing Flooding and SuDS when Improving Drainage and Sewerage Systems-A Comparative Study of Selected Scandinavian Cities
}

\author{
Geir Torgersen $^{1,2, *}$, Jarle T. Bjerkholt ${ }^{1,3}$ and Oddvar G. Lindholm ${ }^{1}$
}

1 Department of Mathematical Sciences and Technology, Norwegian University of Life Sciences, 1430 Ås, Norway; E-Mails: jarle.bjerkholt@nmbu.no (J.T.B.); oddvar.lindholm@nmbu.no (O.G.L.)

2 Faculty of engineering, Østfold University College, 1757 Halden, Norway

3 Central Administration, Telemark University College, 3901 Porsgrunn, Norway

* Author to whom correspondence should be addressed; E-Mail: geir.torgersen@hiof.no; Tel.: +47-48-35-04-80.

Received: 18 December 2013; in revised form: 24 March 2014 / Accepted: 25 March 2014 / Published: 2 April 2014

\begin{abstract}
Pluvial flooding already challenges the capacity of drainage and sewerage system in urban areas in Scandinavia. For system owners this requires a stricter prioritization when improving the systems. Experts seem to agree that a regime shift from improving old combined sewers by piped solutions to more sustainable drainage systems (SuDS), must take place. In this paper results from an investigation amongst the largest cities in Norway, Denmark and Sweden concerning drivers and preferred methods for improving the old system are presented. The results indicate that Norway ranks flood prevention lower than the other Scandinavian countries. During the last decades, Norwegian authorities have had a strong focus on pollution from wastewater treatment plants (WWTP). The attention to drainage and sewerage system regarding flooding, water leaks, infiltration or pollution has been neglected. Renewal or rate of investment in relation to existing drainage and sewerage system is easy to register, and provides a measure of the activity. In order to optimize flood prevention, and may be promoting the use of SuDS, the cities should be required to measure the efficiency, either by monitoring or modeling the impact of stormwater to the system. Lack of such requirements from Norwegian authorities seem to be a plausible explanation to why Norwegian cities are less focused on flood prevention compared to Swedish and Danish cities.
\end{abstract}


Keywords: flood control; urban water; Scandinavia

\section{Introduction}

In a period with changing climate, impacts on both precipitation patterns and urban drainage will occur [1]. Increasing total rainfall and rainfall intensity will result in a greater load on the drainage and sewerage systems. These important infrastructure systems were designed and built years ago, and increased precipitation was not part of the design criteria. In addition, improper maintenance, aging etc. causes many problems. In Norway more than half of the systems are built before 1980 [2], and in central parts of the cities you will find the oldest systems.

Conventional piped drainage systems are designed for specific maximum flow rates and will be unable to meet the increase in the water volume [3]. Sustainable Urban Drainage Systems (SuDS) like ponds, open ditches, green roofs, etc. are in many countries made for stormwater treatment. In urban areas in Scandinavia the authorities only to a small extent have required stormwater treatment, and SuDS have then largely been considered as a flood prevention measure e.g., in Malmö, Sweden [4]. It has been shown e.g., in Denmark and Germany that decentralized solutions for stormwater handling are more flexible than conventional drainage systems. This flexibility is important when dealing with the uncertainties regarding future consequences [5-8]. An Irish study [9] concluded that although the benefits of SuDS are obvious, they are not sufficiently appreciated. The water and wastewater sector is considered to be very conservative [10,11], and the engineering culture is often referred to as a key barrier to implementing sustainable approaches in practice $[11,12]$.

The Norwegian governmental report "Adaptation to a changing climate" released in December 2010, points to the many challenges that Norway is facing in relation to global climate change [13]. The future pace and scale of expected climate change are unknown, and implementing good and adaptable systems today is therefore a prerequisite for a less vulnerable Norway in the future. Urban areas are expected to be areas where the climate changes will be most apparent in everyday life [14]. Population growth and more impermeable surfaces due to more buildings, roads, parking lots, etc. are causing increasing strain on the drainage systems in the cities. A change to more sustainable stormwater systems in cities can reduce possible flooding in the urban environment [15].

Norwegian cities, like cities in many other countries, already experience challenges related to urban flooding. There are mainly three reasons for this: Climate changes, rapid urbanization and under-designed sewers [16]. The current pipes in the drainage systems in Norway cannot easily be replaced by larger pipes [17]. Heavy rain storms can lead to a runoff situation where the pipe capacity is exceeded, resulting in flooding events and backflow of wastewater into buildings and basements. This is already a major problem in several Norwegian cities [13]. So far, there has been limited development of lokal overvannsdisponering-LOD (Local Stormwater Handling), which cover both infiltration and detention and is the Norwegian term that best corresponds with SuDS [18].

The organization of the wastewater sectors in the Scandinavian countries is comparable. Water distribution- and wastewater services in Scandinavian cities are all public services. The main systems are directly or indirectly owned by the municipalities and are managed either by their own employees 
or contracted professionals. The municipalities in all Scandinavian countries have for decades been encouraged by the national authorities to increase the use of SuDS [19-21]. The similarities in organization of the wastewater sector make it possible to investigate differences in how future challenges are met, and if this is reflected in the prioritization of the measures. There are some historical differences, while Denmark traditionally dimensioned their combined sewer for a 2 years flood recurrence interval before 1990 [21], Norwegian authorities recommended 5-years [22]. Regarding the responsibility for basement flooding from sewers, Norwegian municipalities have stricter obligations than in Sweden and Denmark [18].

Flood prevention measures involve many stakeholders with different perspectives although they are often seen in multidisciplinary cooperation. It is generally believed that climate changes are expected to cause more flooding in urban areas in the future [1,6,15,17], but how these changes will develop are not further discussed in this paper. Much of the impact of heavy rainfall in urban areas, are related to the drainage and sewerage system. The aim of this paper is then to investigate how the system owners' in practice are focusing on measures to reduce or prevent problems with pluvial flooding in urban areas e.g., backflow and flooding of basements. This includes measures either to avoid, delay or convey stormwater in the system. This is believed to be a challenge in urban areas worldwide, but as a basis for this study, a survey among the largest Scandinavian cities was carried out. Since this study deals with urban flooding, it was assumed that the largest cities were the most relevant selection for the study. The hypothesis was that the system owners in Norway, when improving old drainage and sewerage system, have little focus on flood-prevention, while other Scandinavian countries dealing with the same challenges rank flood prevention higher. In this paper, the term improvement is used independent of whether the methods are convential (renovating or renewing the piped sewers) or using SuDS. Summarized, the aims of this study are:

- How prioritized is flood prevention when Norwegian cities are improving their drainage and sewerage system? To what extent are SuDS the preferred method when improving the system?

- Are there any differences amongst the Scandinavian countries in how the cities or the national authorities meet this issue?

Key factors, such as technical conditions, incidents, economy and competence are believed to affect the priorities which are chosen. These factors are compared to identify possible causes for why flood prevention in urban areas is prioritized differently in the Scandinavian countries.

\section{Background}

The annual precipitation in Norway has increased by $20 \%$ during the 1900 s, and some places it has increased with almost 2\% per. 10 years some places since 1980 [13]. Extreme rainfall events in Norway are expected to increase slightly up to 2025, and then sharply towards 2050 [23]. In small catchments areas (20-50 ha), the maximum flow will normally occur during the summer months [24]. It is estimated that it will continue to rise with an average of 13\% in the period 2071-2100 compared to 1961-1999 [16]. In the period 2071-2100, the intensity of the heaviest summer rains in Oslo is estimated to be $20 \%$ higher than today [25], while corresponding rains in the autumn are expected to become $40 \%$ higher than today. A comparison of extreme rainfall events with 24 hour durations from 
the past 100 years [26], show only small variations between the Scandinavian countries regardless of the return period and season. The western coast and mid-Norway experience the greatest extreme weather conditions in Scandinavia. However, only small differences are found when comparing specific measurements from the capitals of each country.

Precipitation and flooding in cities result in a number of social costs such as traffic disturbance, damage to infrastructure and buildings, sick leave due to infectious water, lost sales for businesses, pollution of drinking water and local recipients [24]. The insurance companies believe that these costs could increase by $40 \%$ or more over the next ten years. This estimate does not include conditions that are defined as natural disasters. The insurance companies are therefore working on a strategy to handle the expected increase in damages. They consider transferring more risk to both private homeowners and municipalities, if they are not willing to adapt to the assumed climatic changes [17]. There have been several court cases regarding heavy urban flood damages in recent years (e.g., Fredrikstad, Stavanger, Alta) $[27,28]$. All these cases have emphasized that insurance companies in the future will hold the municipalities more liable for flooding related to insufficient capacity of the mains. Not all costs are easy to determine, but from 1992 to 2007, Norwegian insurance companies paid 3000 million EUR in compensation for water damages. The expenses rose each year during the period, most likely due to frequent torrential rains and more rain in general. It is estimated that approximately $25 \%$ of these payments were due to flooded houses caused by insufficient urban drainage system [29].

In recent years, there have been several damages caused by heavy rain in Norway, for instance in Fredrikstad (August 2008) and in Drammen (August 2012), which resulted in major damages. Sweden has been less exposed to urban flooding, but some extreme events have caused significant social costs. Copenhagen in Denmark had a major rainfall in the summer of 2011. This is one of the clearest examples of extreme rainfall, which have consequences both for housing and infrastructure. Total insurance payments amounted to about 800 million EUR, distributed among approximately 80,000 cases [30,31].

Even though it is not possible to make an exact comparison, the above shows that there are many common challenges, and focus on flood prevention measures in urban areas should then be ranked almost equally in the Scandinavian countries.

\section{Theory}

The capacity of stormwater systems may be increased by new and larger pipes when old pipes cause problems with flooding, pollution, etc. This conventional method is no longer seen as sustainable [32], and if possible, it is increasingly replaced by non-piped solutions in more and more countries. How far this trend has been developed in different countries, vary widely, and great diversity is seen even within countries. In urban areas, it is not realistic to establish stormwater systems that completely consist of non-piped solutions. However, it is important to plan for an ever-increasing flood risk, and take into account that this will be an even greater challenge in the future. For a city, optimal measures will rarely consist of one single method, but a selection of sustainable solutions adapted for local conditions and requirements.

In the wastewater sector like many other sectors, a dominating way to solve a social subtask can be denoted as a regime, and such a regime is typical for the way we meet the societal needs [33]. Other regimes, which have a power are denoted niche-regimes, although they are not dominating the way 
that the societal needs are met. Niche regimes fundamentally challenge the dominant regime. A change in which a niche-regime emerges, and finally oust the dominant regime, may occur. The dominant regime will at any time be what protects the society's needs in the best way. This transitional change is denoted regime shift. The speed of this transition is influenced by a complex number of conditions, which drive the transition.

According to Ashley, et al. [34] the societal system is composed by a number of societal subsystems, and storm water management in cities is an example of such a social subsystem. The way to solve these challenges in cities, deals with two fundamentally different competing regimes. The developed part of the world is at different stages in the transition from the traditional storm water regime to other systems. The old regime, which in most cases also is the current regime, is to improve the system through piped solutions either by combined or separate systems. They state that the traditional piped solutions for handling storm water are the dominant regime in most cities. Changes in boundary conditions (i.e., more flooding as a consequence of climate changes) may change the society's opinion and help the niche to develop. But a sudden increase in flooding events may be met by the decision makers by conventional renewing methods, because there is no time for untested methods as SuDS. Thus, the uptake of this niche may be delayed. However, the development of SuDS has come with an increasing focus at the possible impact of climate changes [35]. It is then assumed a transition towards the new and more flexible regime for storm water management will occur.

\section{Methods}

A general theoretical model [33], adapted by Ashley et al. [34], is used in this context. The increased attention to flooding as a target and SuDS as a preferred method to solve this is illustrated in Figure 1 as a transition line between the old and the new regime. According to Geels [36], the conceptual characteristics of a regime transformation is that the regime insiders gradually change their cognitive beliefs and behavioural norms.

Figure 1. Transition line toward a sustainable urban drainage system (SuDS)-focused regime.

\begin{tabular}{|ll|}
\hline TRADITIONAL REGIME & EXPECTED FUTURAL REGIME \\
Regime for & Regime for \\
piped & SuDS \\
stormwater & \\
solution & Higher focus \\
Focus on & on flooding \\
flooding & \\
\hline
\end{tabular}

In step 1 of this survey a comparison between Norway and other Scandinavian countries was made, both in regard to the target for the improvement and the methods used.

The next step of this study was to make a model of factors that influence the present regime. These are the factors that combined can provide an explanation for the situation in each country, as shown in Figure 2. The factors are interrelated, and can be viewed as a continuous improvement process. Bos and Brown illustrated this in a broader perspective as "Phases of governance experimentation leading 
to adaption in water governance structures...". They mention this as strategic, tactical, operational and reflexive activities [12]. When a goal and a desired condition are achieved, new goals will be set and the process starts over again. The purpose of the model is to identify relationships between individual factors that may explain the differences, which are found in step 1.

Figure 2. Factors affecting flood and SuDS-focus_-illustrated as a continuous process.

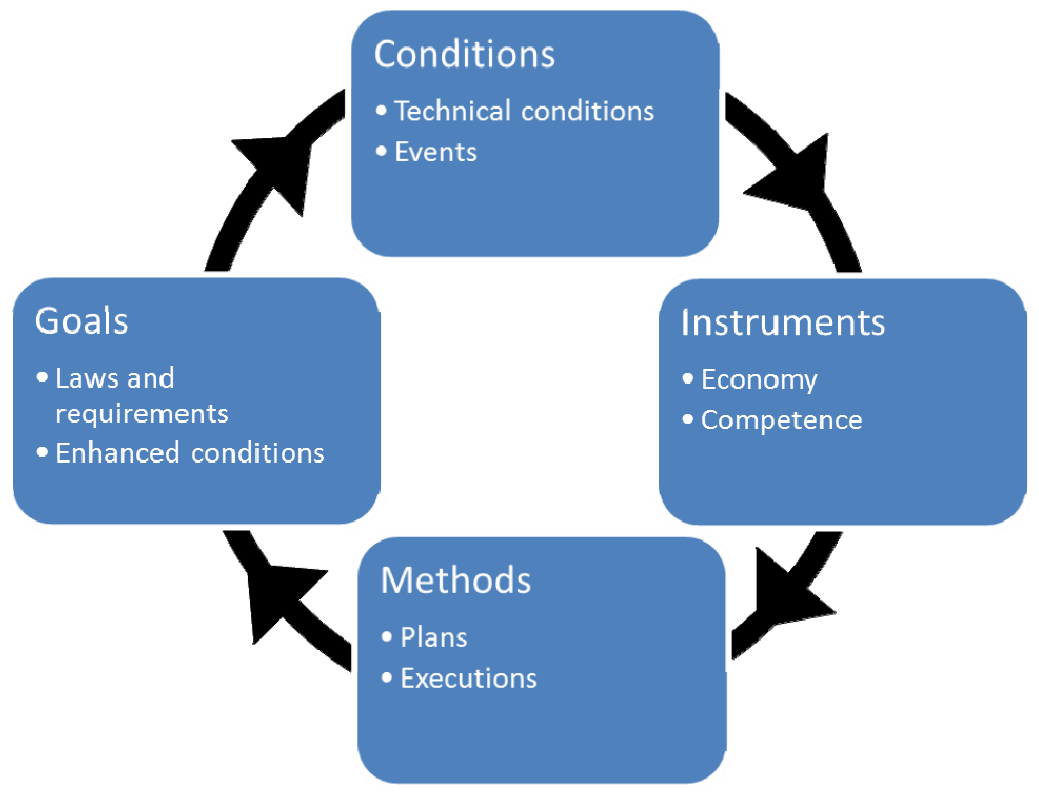

The model in Figure 2 can be used to compare any urban wastewater systems, (e.g., cities or companies). In this study, however, the model was used to compare the SuDS-focus in the Scandinavian countries. Within each factor, some quantitative and relevant parameters were identified and compared. In Figure 2, the term Conditions is used to describe the state of the technical facilities and the consequences of this condition. Renewal rate, the rate of combined systems or the amount of infiltrated water are all indicators for the conditions of the drainage and sewerage systems. In addition, water leaks are used as an indicator because this causes more water to infiltrate the drainage system, and affects the choice of method for repairing the system. In this study, the term events includes registered damages at insurance companies and economic costs of extreme rainfalls. Instruments are factors that can be utilized to change the conditions, e.g., the financial resources the owner is willing to spend and available expertise. This will mainly include professionals, but in an initial phase it may also include politicians and the citizens as well. The term Methods is used for the possible physical measures. These are again seen as a result of choices and strategies that have been taken to improve the condition of the system. The primary Goal in relation to this will be to reduce the risk of flooding. Within the wastewater sector, many of these goals are regulated by the EU Framework Directive, which is current legislation in all Scandinavian countries.

The survey was made out to capture trends, and it was designed to create a holistic view for the largest cities in Scandinavia. This study did not deal with the rate of change or the actual transition to a new regime. The results of the study were viewed in the light of the models described in Figures 1 and 2.

The wastewater plan, like other urban development plans, does not give a complete picture of how and why the cities prioritize new projects in practice [37]. The plans do not always show the preceding 
ideas and internal discussions among professionals. Therefore, the personnel managing the wastewater sector in each city were contacted and asked to take part in the survey. It was assumed that these persons have a great influence on the decisions for planning and implementing renewal projects. The largest cities are supposed to be the most relevant selection when it comes to urban flooding [38]. Smaller communities might be less vulnerable to flooding due to a higher proportion of natural green areas in the vicinity. However, they might also lack engineers to provide adequate solutions to flooding problems. Accordingly, small cities were excluded from the study, since these are expected to encounter different challenges than larger ones. In addition, the major cities in each country are expected to reflect the "national best practice" in relation to urban flooding. The current study analyses drivers and methods used by system owners for improving the drainage and sewerage systems, based on completed projects in the chosen reference year 2010.

Initially 10 Norwegian cities were visited in May-June 2012 and interviewed based on a qualitative study. This was done to get an overview of the state and to confirm the validation of the questions. Then the remaining 15 of the 25 largest cities were contacted and accepted to receive a questionnaire, which later was sent by mail. Respondents were asked questions about the improvements of existing drainage and sewerage system in a given reference year (2010). The key questions were triggering reasons and used methods when improving the system. In addition, they were asked questions about the condition of the system, availability of staff, and financial constraints. A similar study was done in Sweden and Denmark during winter 2012/2013. Based on the experience from Norway, three cities were visited and interviewed to confirm the questions. The rest of the cities among the 25 largest, were contacted and accepted participation in the questionnaire, which later was sent by mail.

From the survey in Norway, 22 of 25 cities (88\%) responded. Similar numbers in Sweden were 14 of $25(56 \%)$ and in Denmark 16 of $25(64 \%)$. In addition to the questionnaire, quantitative data from national registers (Bedre VA (Norway), VASS (Sweden) and Danva benchmarking (Denmark)) for the reference year 2010 were collected. Even though the study was limited to the largest cities in the considered countries, the difference in population in the cities in the survey was substantial. Accordingly, weighting the results by the economy or population of the cities would result in a bias towards the trends in the largest cities (weighted answers from the smallest cities would have counted only $5 \%$ to $10 \%$ relative to the largest cities). Since the goal was to capture trends, the use of non-weighted averages for each country was selected.

There are obvious differences between the Scandinavian countries that must be taken into account before analyzing the results of the survey. The median number of inhabitants in the Norwegian cities that responded was approximately 47,300, while the corresponding numbers in Sweden and Denmark were 98,900 and 94,800 , respectively. It is not reasonable to assume that the results from the larger cities are representative to smaller cities with less manpower, less financial resources and less population density. However, in this study there was no significant trend that the larger cities used other methods and had different reasons to improve the system than the smaller ones.

The results were related to the theory described above and presented in two steps. Step 1 was based on the responses to the questionnaire of selection process and methods for improvement projects in a given reference year. The results of this were used to calculate Norway's position in the transition towards a more sustainable storm water regime compared to Sweden and Denmark. In step 2 
additional results from the survey, national benchmarking and literature review were used to find the underlying reasons for the differences between the considered countries.

\section{Results}

This study primarily investigates how cities were dealing with flood prevention. However, it also included an investigation regarding how measures in relation to existing drainage and sewerage system were undertaken. Measures are planned and conducted by the same professionals, and often carried out at the same time and need to be within a given budget. It was therefore relevant to compare the different triggers for improvement projects.

In step 1 of the survey, the engineers in the cities evaluated both the triggering cause and method in the reference year 2010. A project can have multiple purposes, and therefore the triggers could be somewhat more difficult to determine than the methods. However, they were requested to state what they believed were the main triggers. It is reasonable to assume that some causes require specific methods, thereby providing a close connection between them. It is accordingly appropriate to discuss these answers together. The distribution of causes triggering projects in the existing drainage and sewerage system in the largest Scandinavian cities in 2010, are shown in Figure 3.

Figure 3. Causes triggering improvement projects in existing drainage and sewerage systems in the largest Scandinavian cities in 2010.

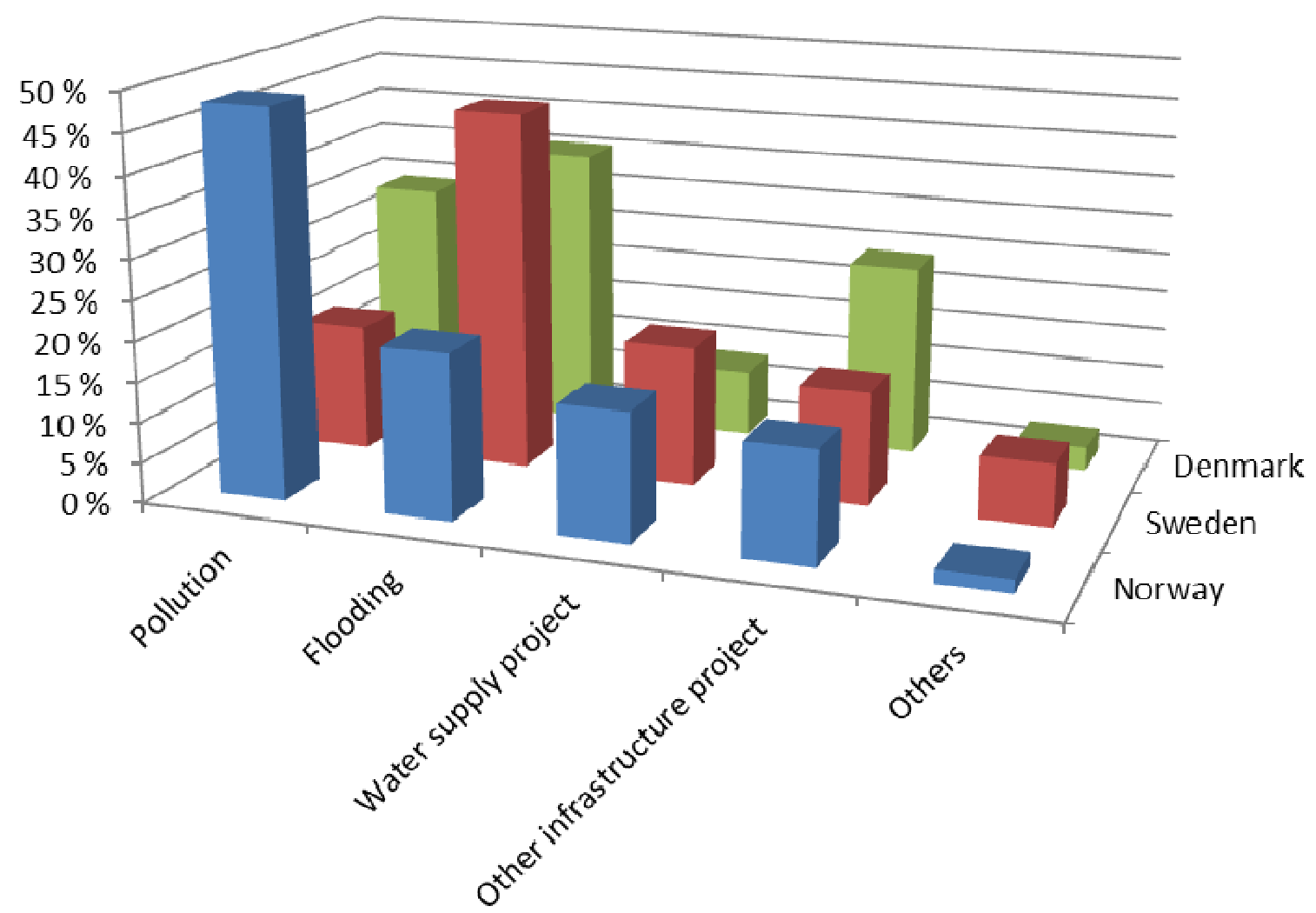

When comparing this, life-cycle analysis (LCA) or other tools could have been useful [39], but in Figure 4 the projects are ranked by the financial investments. Open trench means digging up and replacing old sewers, while No-Dig covers relining, blocking or other possible methods for renewing 
the old pipe without digging. SuDS include non-piped solutions as ponds and open ditches trench, mainly built for flood protection. Compared to many other methods, SuDS are normally less capital intensive, and the amount spent on sustainable solutions is expected to be far lower than other methods such as open trench.

Figure 4. Methods used to improve existing drainage and sewerage systems in the largest Scandinavian cities 2010.

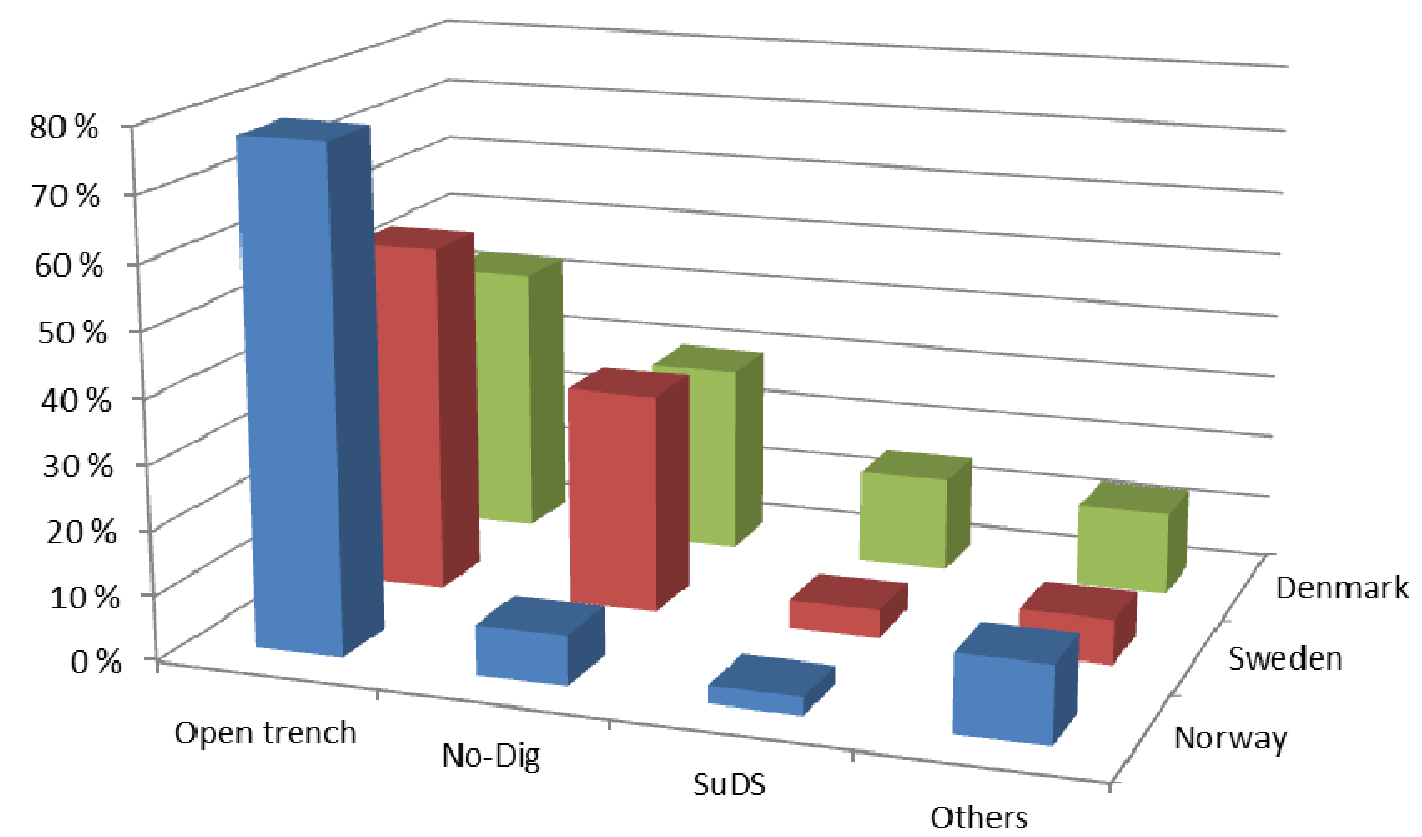

Some clear trends in relation to flooding were found in the survey and are shown in Figures 3 and 4:

- Compared to Sweden and Denmark, there were fewer cases in Norway where prevention of flooding was the triggering factor to wastewater projects. Pollution was reported to be the main reason for most drainage projects in Norway, far more important than in the other countries.

- Sustainable methods of stormwater management were used more frequently in Denmark than in the other countries.

In Figure 4 it is shown that SuDS was rarely used in Norway, in average it is only 3\% which confirms previous research [18]. More than $80 \%$ of the Norwegian cities report that they did not use SuDS at all in 2010. Approximately $45 \%$ of the Swedish and $10 \%$ of the Danish cities reported the same. The findings indicate that both Denmark and Sweden are more focused on flood prevention measures.

Based on the results shown in Figures 3 and 4 it is not possible to see a correlation between focus on flooding and the use of SuDS. However, it seems to be a trend that Norwegian cities are more one-sided and traditional both in their targets and choice of methods to improve the drainage and sewerage system.

The limited focus on SuDS indicates that Norway is placed to the far left in Figure 1. Based on the same criteria, the survey indicates that Danish cities have made most progress in the development towards a more sustainable stormwater regime.

In step 2 of the study, the model in Figure 2 was discussed with an intention to explain the differences in step 1. Factors assumed to be relevant are shown in Table 1. 
Table 1. Comparison of factors that may affect flooding and SuDS-focus.

\begin{tabular}{|c|c|c|c|c|}
\hline Factors & Characteristics & $\begin{array}{c}\text { Characteristics for } \\
\text { Norwegian cities (N) }\end{array}$ & $\begin{array}{c}\text { Characteristics for } \\
\text { Swedish cities (S) }\end{array}$ & $\begin{array}{l}\text { Characteristics for } \\
\text { Danish cities (DK) }\end{array}$ \\
\hline \multirow{6}{*}{ Conditions } & Rate of combined sewers $(2010)^{1}$ & $31 \%$ & $13 \%$ & $48 \%$ \\
\hline & Renewal rate $(2010){ }^{1}$ per. Year ${ }^{1}$ & $0.74 \%$ & $0.38 \%$ & $1.07 \%(2000-2010)$ \\
\hline & $\begin{array}{l}\text { Number of basements flooding in } \\
\text { houses caused by the drainage and } \\
\text { sewerage system } 2008-2010^{2}\end{array}$ & $6,000-6,500$ & 6,000 & $\begin{array}{l}6,000-9,000 \\
(2008-2009), \\
20,000(2010) \\
\end{array}$ \\
\hline & $\begin{array}{l}\text { Infiltrated water in the largest } \\
\text { treatment plants in } 2009^{3}\end{array}$ & $68 \%$ & $58 \%$ & $23 \%$ \\
\hline & $\begin{array}{l}\text { Leakage from drinking water } \\
\text { networks } 2010^{1}\end{array}$ & $43 \%$ & $23 \%$ & $9 \%$ \\
\hline & Cities reporting lack of capacity ${ }^{4}$ & $32 \%$ & $7 \%$ & $7 \%$ \\
\hline \multirow{4}{*}{ Instruments } & Fee for a standard residential (2010) ${ }^{1}$ & 225 EUR per year & 173 EUR & 359 EUR \\
\hline & $\begin{array}{c}\text { Cities reporting good or adequate } \\
\text { financial frames to improve the } \\
\text { systems }{ }^{4}\end{array}$ & $95 \%$ & $42 \%$ & $80 \%$ \\
\hline & $\begin{array}{c}\text { Cities reporting shortage of internal } \\
\text { professionals }{ }^{4}\end{array}$ & $59 \%$ & $64 \%$ & $23 \%$ \\
\hline & $\begin{array}{c}\text { Cities reporting shortage of available } \\
\text { external expertise }^{4}\end{array}$ & $26 \%$ & $29 \%$ & $0 \%$ \\
\hline \multirow[t]{2}{*}{ Methods } & Use of methods (ref. Figure 4$)^{4}$ & $\begin{array}{l}\text { Most use of } \\
\text { open trench }\end{array}$ & $\begin{array}{l}\text { Less use of open trench, } \\
\text { more use of No-Dig } \\
\text { compared to N }\end{array}$ & $\begin{array}{c}\text { Less use of open } \\
\text { trench, more use of } \\
\text { No-Dig compared to N }\end{array}$ \\
\hline & $\begin{array}{l}\text { Number of cities invested in SuDS } \\
\qquad(2010)^{4}\end{array}$ & $18 \%$ & $54 \%$ & $92 \%$ \\
\hline
\end{tabular}

EU Water Framework Directive is the most relevant international legislation in the sector and is basically the same in all Scandinavian countries. In $\mathrm{S}$ the EU Flood directive is implemented for urban flooding, in contrast to $\mathrm{N}$ and $\mathrm{DK}$.

Goals N reports activity in the voluntary national benchmarking (Bedre VA) and required national reporting (KOSTRA). Both S and DK report the activities as in N. No reporting of emissions from transport system is required in N. Most of the cities in S and DK report emissions from all CSOs. In S this is reported to the regional, and in DK to national environmental authorities.

Notes: ${ }^{1}$ Data from national benchmarking (Bedre VA, VASS, DANVA benchmarking) for the 25 largest cities in each country which have registrated data; ${ }^{2}$ Comparable insurance data. For Norway and Denmark 2008-2010, for Sweden 2010 [40-42]; ${ }^{3}$ According to Lindholm, et al. [43]; ${ }^{4}$ Survey of the largest cities in Norway, Sweden and Denmark related to this paper.

\section{Discussion}

\subsection{Conditions}

When evaluating the technical condition of the drainage and sewerage systems in relation to flooding, it is relevant to compare the share of combined sewers. From Table 1 it can be seen that both Norway and Denmark have significantly more combined sewers than Sweden, and from Table 1 it can be seen that leakage from drinking water network is significantly higher in Norway compared to 
Sweden and Denmark. Even if leaks from water pipes into sewers are unaffected by precipitation, it is relevant in this context, because it causes reduced capacity to handle extreme rainfall.

Infiltrated water is defined as any unwanted water entering the sewers and is, according to Lindholm et al. [43], higher in Norway than in the other Scandinavian countries. Much infiltrated water results in extra large flow during periods with heavy rainfall. As an additional question, the cities were requested to make subjective evaluations of the sewers. The responses fit well with the study of infiltrated water. Evaluated on the basis of capacity, the Norwegian cities are rather more pessimistic than in the other countries, and approximately 30\% state capacity as poor/reduced. Among the Swedish and Danish cities, less than $10 \%$ report this.

An effect of poor condition of the systems is a high number of registered flood damages after large rainfall events. To identify challenges from urban flooding in Scandinavia, the number and cost of flooding from sewers registrated by insurance companies can be compared. From the Norwegian register of water related damages [40], the number of damages from 2008 to 2010 were about 6000-6500 per. year and with an estimated cost of $c a$. 35-40 million EUR each year. Statistics from Sweden the recent year [41] have estimated that these costs are 30-35 million EUR. Sweden is almost twice as densely populated as Norway. The number of damages due to lack of capacity of the drainage systems is low from the Swedish insurance companies' point of view [44]. Even if it is an increasing problem, it is not yet seen as a big challenge compared to other kind of damages. In Denmark there are statistics for cloudbursts [42], but this is not separated into the different kind of damages. In Denmark, the number and cost of damages was estimated to be at same level as Norway in 2008-2009, but it was more than doubled in 2010 . However, this increase is probably linked to differences in spesific events, and not to the conditions of the systems.

Comparison of several parameters describing the current state indicate that Denmark has experienced more damages caused by some spesific incidents, while Norway has significantly greater challenges in terms of the technical conditions of the sewers than Sweden and Denmark.

\subsection{Instruments}

According to the selected instruments, the survey generally showed a more positive trend in Danmark. They were less conserned about the capacity and had fewer challenges in recruiting professionals than Norway and Sweden.

Both Sweden and Denmark have an opportunity to levy a separate stormwater fee [45,46], which may lead to consciousness for sustainable stormwater treatment. Sweden and Norway have significant lower fees than Denmark. The cities were asked whether they had sufficient financing to improve the drainage and sewerage systems in the reference year 2010. Although the Norwegian cities had lower fees than Denmark, the professionals in Norway are more positive to the available financial resources than the largest Danish cities. A comparison of instruments indicates that Norway has a challenge in recruiting enough professionals. There are also strong indications that they have lower ambitions in relation to what is sufficient economic framework to improve the system.

For the Swedish cities, it is a more significant correlation between low fees and dissatisfaction of the financial frames of the drainage and sewerage systems. 


\subsection{Methods}

The results presented in Figure 4 indicate that replacing old pipes is far more common in Norway than in the other Scandinavian countries. This means that old combined systems were dug up and replaced with separate sewers. The method is both expensive and time consuming in urban areas, but is a safe method to reduce pollutant emissions, provided that all private service pipes in the area is in good condition or replaced at the same time. The municipal engineers in Norway are more satisfied with the financial framework than in the other countries. This may be the reason why they often choose to improve the system by open trench. Moreover, Table 1 shows that water leaks is such a big problem that in many ways the use of full digging is preferred and thus it is suitable to separate the system too.

In the survey, No-Dig-methods seemed to be little used as a renovation method in Norwegian cities in contrast to Sweden and Denmark. According to Lindholm [47] the largest cities in Norway have an ever increasing use of No-Dig as the preferred renovation method. Apart from that, water leaks can enforce open trenches; a possible explanation may be that Norway is less densely populated. Otherwise, there are no clear technical reasons why No-Dig-methods are less used in Norway than in Sweden and Denmark.

As mentioned above, SuDS are found to be significantly more frequently used in Denmark than Norway. One explanation may be that Denmark traditionally has greater need to restore stormwater to the natural environment, since $99 \%$ of drinking water sources in Denmark are groundwater. Accordingly, Denmark already has a tradition of SuDS planning since the 1990s, before the climate changes came into focus.

Methods for improving the wastewater system vary less in Norway than in the other countries. Uniform use of methods may mean that Norway has some extraordinary challenges which only can be solved by open trench. The water leaks from water supply network may be such a challenge. Another possibility is that the current and past requirements do not encourage varying methods in relation to the challenges that arise. As previously mentioned [10], the wastewater sector in Norway is known to be conservative. It may, in addition to shortage of professionals, be the reason why testing of more sustainable methods are prioritized lower than in Denmark.

\subsection{Goals}

EEC and national laws regulate flooding and damage from surface water in all Scandinavian countries. The Water Framework Directive aims at ensuring that all watercourses are returned to a natural state. The Flood Directive requires the responsible authority to do risk analysis to identify potential flood incidents. Actions that ensure the achievement of an acceptable level of risk should be taken by 2015. In Sweden, the EU Flood directive is implemented for urban flooding, in contrast to Norway and Denmark. In addition, there may be differences in national requirements and particularly in how they are practiced.

Both in Sweden [46] and Denmark [48], separate laws for the water- and wastewater sectors have been passed. In Norway, relevant acts governing the wastewater sector are integrated in several laws. The Planning and Building Act, the Water Resources Act and the Pollution Control Act are the most 
relevant laws [24,49]. Although sector laws have given the wastewater management increased attention in Sweden and Denmark, the short time since these laws were passed suggest that this is probably not the main explanation for why Norway has different priorities.

In terms of preventing flooding, it is particularly interesting to compare the requirements from the national authorities regarding the impact of stormwater to the drainage and sewerage system. The way in which the requirements from the authorities have been given and controlled appears to have varied since the 1990s. The investigation indicates that Norwegian cities, in the reference year 2010, have the same priority as they had before climate change became an issue.

Interestingly, the Norwegian pollution authority has not demanded monitoring or modeling the efficiency of the improvements in the network during the last 20 years. Accordingly, Norwegian cities have never had any incentives to monitor these themselves. Thus, it has not been possible to evaluate the impact of the measures that has been taken, nor is it clear whether the main reason for improvement was to achieve reduced pollution or flood control. Ever since the 1990s, the National authorities in Sweden and Denmark have had a greater focus on monitoring combined sewer overflows (CSO) from sewers than Norway. In Sweden, the overflow values were made public through the EMIR registry to the county administrative board [50]. It was demanded that the overflow volume from sewers which served WWTP designed for more than 500 pe (population equivalents), should be monitored [51]. In Denmark, this is reported by Danish Nature Agency [52]. It appears that the requirements to monitor overflow from transport systems have been the focus of the national authorities in both Sweden and Denmark. In contrast to Norway, this might have made the cities more aware that the emissions from transport systems should affect the priorities when deciding where and how measures are taken.

\subsection{Considerations Concerning Improvement as a Continuous Process}

In Figure 2, the development process is drawn as a circle, which illustrates that this is a continuous process. Accordingly, when a goal has been reached, for example by an implemented wastewater plan, better conditions are achieved. Thus, the process will commence with a new starting point, and new choices and priorities based on changed conditions will emerge. How to measure and compare the original and the improved condition of the drainage and sewerage system is significant, since this confirms whether the instruments and methods have been optimized.

An indication of the focus Norwegian authorities had in the 1990s is given by Bull [53]. In 1996, it was articulated in a speech by the junior minister in the Royal Norwegian Ministry of the Environment that the goal was to clean up the sewage sector in Norway by the year 2000. It was focused on how to finalize the separation of combined systems, and improving treatment plants within a few years. Guidelines from the regional environmental authorities [54,55] show that the quantitative requirements through the 1990s and 2000s applied only to overflow from wastewater treatment plants. According to Farestveit [56] the Norwegian authorities were concerned about overflow from CSOs in the 1990s, but unfortunately this attention declined in the 2000s.

The survey showed that Norwegian cities have less variation in the use of improvement methods. Open trench, which is a traditional method, was more frequently used in Norway than in the other Scandinavian countries. This fits the findings that Norway has limited internal personnel resources, but 
acceptable economic constraints. When Norwegian cities specify triggers for a specific project, this is probably based on the intentions for the project. Since loss from transport systems is seldom monitored, the assumption that one method provides a better condition is prevailing, e.g., separation is synonym to pollution reduction. It is difficult to verify to which extent the intended goal is achieved. Improvement projects in the wastewater system in Norway have mainly been reported by activities, e.g., renewal rate (meter pipe per year or \% restoration per year) or the investment (amount of money per year). This focus has probably appeared because it is both easy to register and explain to the society. When a significant number of Norwegian cities reported that they currently face major challenges related to infiltration of water into the transport systems, which are recently renewed, there are reasons to question how they register achievement of goals. Lack of requirements may have led to the fact that overflow and other loss from the system have been unknown. Accordingly, the condition and the need for improvements are defined by other, simpler criteria. This may have led to an impression that method and activity are the main goals.

The state of the wastewater system seems to be significantly lower in Norway than in the other Scandinavian countries. There are already considerable challenges to manage increased rainfall. For all countries, and particularly for Norway, it is important to quantify the impact of what has being carried out. More focus on the requirements of measuring the impacts of prioritized projects will probably lead to a more sustainable stormwater management in Norway.

\section{Conclusions}

Current practice for prioritizing new projects in existing drainage and sewerage system in Scandinavia is shown in Figures 3 and 4. The study, which applies to the reference year 2010, indicates:

- Flood prevention measures are less important target in Norwegian cities compared to the other Scandinavian countries. The most important reason when prioritizing projects in the existing systems is reduction of pollution. In both Sweden and Denmark flooding is more frequently given as the reason for initiating and conduct improvement projects;

- Methods for sustainable urban drainage system (SuDS) are rarely used in Norway. Based on the amount of money invested, Denmark seems to have a higher utilization of SuDS-methods than cities in Sweden and Norway, where the same low rate of SuDS-measures are found. There are also differences in the number of cities, which use SuDS. The respondents from Denmark reports $93 \%$, while the corresponding numbers in Sweden and Norway are $54 \%$ and $18 \%$, respectively. Both climate prognoses and increase in insurance damages should indicate that the challenges in Norway are almost the same as in Sweden and Denmark. The condition of Norwegian wastewater system seems to be worse than the other Scandinavian countries. It is therefore reasonable to question why flood prevention and sustainable stormwater handling have such a low priority. The survey was done with reference to the year 2010. The heavy rain in Copenhagen 2 July 2011 or other incidents do not seem to explain the differences.

There are several reasons why Norway has not progressed as far as the other countries in relation to this issue: 
- Denmark use groundwater for water supply. Therefore, the return of stormwater to the natural environment has been part of the Danish engineering culture even before it became the focus of climate changes and extreme weather. To a lesser extent, the same could be the case in Sweden. Norwegian cities use surface water for water supply and have more water resources. Therefore, the initiative for taking such considerations is smaller in Norway;

- Shortage of enough competent personnel both internally and in the external consultancy market, may lead to limited resources for innovation and analysis to find the optimal measures. The survey showed that in Norway the prioritization of new projects are done on the basis of the same considerations, and probably with the same methods, as before climate changes became an issue more than 10 years ago;

- There are indications that the Norwegian authorities' interest and actual requirements for the leakage of wastewater in general, and from the transport system in particular, have been lacking compared to the other countries since the 1990s.

To get a better view and more consciousness about the problem, the Norwegian authorities should introduce stricter demands for documentation of total overflow and leakage from the transport system. This can encourage the Norwegian cities to be more focused on the impacts of improvement projects rather than the activity. Over time, this can lead to a more sustainable stormwater management.

\section{Acknowledgments}

The authors are grateful to professional staff in cities in Norway, Sweden and Denmark which have responded to the survey. We also want to thank the Water-and wastewater associations, National environmental authorities and Insurance companies in the Scandinavian countries for relevant information and statistics in relation to this study. The authors also want to extend thanks to Østfold University College and The Norwegian University of Life Sciences for financing this study.

\section{Conflicts of Interest}

The authors declare no conflict of interest.

\section{References}

1. Grum, M.; Jorgensen, A.T.; Johansen, R.M.; Linde, J.J. The effect of climate change on urban drainage: An evaluation based on regional climates model simulations. Water Sci. Technol. 2006, $54,9-15$.

2. SSB Kommunalt avløp 2012. Available online: https://www.ssb.no/natur-og-miljo/statistikker/ var_kostra/ (accessed on 26 March 2014).

3. Sharma, D. Sustainable Drainage System (SuDs) for Stormwater Management: A Technological and Policy Intervention to Combat Diffuse Pollution. In Proceedings of the 11th International Conference on Urban Drainage, Edinburgh, UK, 31 August-5 September 2008; p. 10.

4. Villarreal, E.L.; Semadeni-Davies, A.; Bengtsson, L. Inner city stormwater control using a combination of best management practices. Ecol. Eng. 2004, 22, 279-298. 
5. Peters, C.; Sieker, H.; Jin, Z.; Eckart, J. Deliverable 2.1.4 Assessing future uncertainties associated with urban drainage flexible systems - The COFAS method and tool. Available online: http://www.switchurbanwater.eu/outputs/pdfs/W2-1_GEN_MAN_D2.1.4_Assessing_future_ uncertainties_urban_drainage_COFAS.pdf (accessed on 26 March 2014).

6. Arnbjerg-Nielsen, K.; Willems, P.; Olsson, J.; Beecham, S.; Pathirana, A.; Gregersen, I.B.; Madsen, H.; Nguyen, V.T.V. Impacts of climate change on rainfall extremes and urban drainage systems: A review. Water Sci. Technol. 2013, 68, 16-28.

7. Refsgaard, J.C.; Arnbjerg-Nielsen, K.; Drews, M.; Halsnaes, K.; Jeppesen, E.; Madsen, H.; Markandya, A.; Olesen, J.E.; Porter, J.R.; Christensen, J.H. The role of uncertainty in climate change adaption strategies-A Danish water management example. Mitig. Adapt. Strateg. Glob. Chang. 2013, 18, 337-359.

8. Sieker, H.; Helm, B.; Krebs, P.; Schlottmann, P.; Tränker, J. Flexibility-A planning criterion for stormwater management. In Proceedings of the 11th International Conference on Urban Drainage, Edinburgh, UK, 31 August-5 September 2008.

9. O’Sullivan, J.J.; Bruen, M.; Purcell, P.J.; Gebre, F. Urban drainage in Ireland-Embracing sustainable systems. Water Environ. J. 2012, 26, 241-251.

10. Aall, C.; Øyen, C.; Hafskjold, S.; Almås, A.; Groven, K.; Heiberg, E. Klimaendringenes konsekvenser for kommunal og fylkeskommunal infrastruktur. Delrapport 5. (Climate change and the consequences for local and regional infrastructure. Subreport 5). Available online: http://www.vestforsk.no/filearchive/r-ks-hindringsanalyse.pdf (accessed on 26 March 2014).

11. Harremoes, P. Integrated urban drainage, status and perspectives. Water Sci. Technol. 2002, 45, $1-10$.

12. Bos, J.J.; Brown, R.R. Governance experimentation and factors of success in socio-technical transitions in the urban water sector. Technol. Forecast. Soc. Chang. 2012, 79, 1340-1353.

13. The Norwegian Ministry of Environment. Tilpassing til eit klima i endring NOU 2010:10 (Adaptation to a changing climate). Available online: http://www.regjeringen.no/upload/MD/Kampanje/ klimatilpasning/Bilder/NOU/NOU-rapport/NOU201020100010000DDDPDFS.pdf (accessed on 13 December 2013).

14. European Environment Agency. Urban adaptation to climate change in Europe, Challenges and opportunities for cities together with supportive national and European policies. Available online: http://www.eea.europa.eu/publications/urban-adaptation-to-climate-change (accessed on 26 March 2014).

15. Semadeni-Davies, A.; Hernebring, C.; Svensson, G.; Gustafsson, L.G. The impacts of climate change and urbanisation on drainage in Helsingborg, Sweden: Combined sewer system. J. Hydrol. 2008, 350, 100-113.

16. Nie, L.; Lindholm, O.; Lindholm, G.; Syversen, E. Impacts of climate change on urban drainage systems-A case study in Fredrikstad, Norway. Urban Water J. 2009, 6, 323-332.

17. Lindholm, O.; Bjerkholt, J. Konsekvenser av flomskader i byer som følge av klimaendringer (Consequences of flooding in cities due to climate change). Available online: http://www.nmbu.no/institutter/imt/forskning-ved-imt/514 (accessed on 26 March 2014).

18. Langeland, E. Implementering av Lokale Overvannsløsninger (Implementation of Local Stormwater Management); Norwegian University of Life Sciences: Ås, Norway, 2011; p. 67. 
19. SFT Norway (Climate and Pollution Agency). Veiledning ved Infiltrasjon av Overvann-Metoder og Tekniske Løsninger (Guidelines for Infiltration of Stormwater-Methods and Technical Solutions); Statens Forurensingstilsyn: Oslo, Norway, 1982.

20. Svenskt Vatten (The Swedish Water \& Wastewater Association SWWA). Lokalt omhändterande av dagvatten (Local stormwater disposal); Svenska vatten och avloppsverkföreningen: Stockholm, Sweden, 1983.

21. Anthonisen, U.; Inge, F.; Hovgaard, J.; Jacobsen, P.; Steen Mikkelsen, P. Lokal afledning af regnvand (local stormater disposal); Miljøstyrelsen: Copenhagen, Denmark, 1992.

22. Lindholm, O.G.; Engan, J.A.; Rapp, Ø.; Petersen-Øverleir, A.; Markhus, E. Revurdering av beregningskriterier for avløpssystemer, flom $i$ kommunale avløpssystem (Reconsidering the dimensioning criteria for the sewerage system); NIVA-Norsk Institutt for Vannforskning: Oslo, Norway, 2003.

23. Førland, E.J.; Alfnes, E. Climate Change and Natural Disasters in Norway: An Assessment of Possible Future Changes; Norwegian Meteorological Institute: Oslo, Norway, 2007.

24. Lindholm, O.; Endresen, S.; Thorolfsson, S.; Sægrov, S.; Jakobsen, G.; Aaby, L. Veiledning $i$ klimatilpasset overvannshåndtering (Guidance on climate adapted stormwater management); Norsk Vann BA: Hamar, Norway, 2008; Volume 162.

25. Nilsen, V. Urban Drainage in the Face of Climate Change: Adaptation of Regional Climate Model Output for Rainfall-Runoff Simulations in Oslo, Norway; Norwegian University of Life Sciences: Ås, Norway, 2008.

26. Agersten, S. Analysis of Extreme Daily Precipitation and Return Periods in Norway and NORDKLIM Area; Norwegian Meterological Institute: Oslo, Norway, 2002.

27. Lindholm, O.; Schilling, W.; Crichton, D. Urban Water Management before the Court: Flooding in Fredrikstad, Norway. J. Water Law 2006, 17, 204-209.

28. Ebeltoft, M. Naturskader og overvann i forsikring. Available online: http://www.sintef.no/ uploadpages/282757/5_Klimatilpasning\%20\%20VA\%20dagenen\%20midt\%20norge\%2012\%20s ept.pdf (accessed on 26 March 2014).

29. Nyeggen, E. Gjensidige Forsikring Klimaendringene-Nye Utfordringer for Forsikring? (Climate Change-New Challenges for the Insurance Industry?) Available online: http://www.forsikringsforeningen.no/wp-content/uploads/2012/08/2007-Nyeggen.pdf (accessed on 26 March 2014).

30. The Danish Government, Sådan håndterer vi skybrud og regnvand, Handlingsplan for klimasikring av Danmark (How we deal with torrential rain and storm water, Action Plan for climate proofing in Denmark). Available online: http:/www.klimatilpasning.dk/media/566642/ klimahandlingsplan.pdf (accessed on 13 December 2013).

31. Johansen, N.B. Erfaringer fra 2 timers regnen i København (experiences from the 2-hours of rain in Copenhagen July 2, 2011). In En blå/grønn fremtid-vårt ansvar-Overvannshåndtering, October 23-24, 2012; Tekna: Gardermoen, Norway, 2012.

32. Kennedy, S.; Lewis, L. Attaining the most sustainable solution in stormwater control in England and Wales. In Proceedings of the LESAM 2007, 2nd Leading Edge Conference on Strategic Asset Management, Lisbon, Portugal, 17-19 October 2007. 
33. De Haan, J.; Rotmans, J. Patterns in transitions: Understanding complex chains of change. Technol. Forecast. Soc. Chang. 2011, 78, 90-102.

34. Ashley, R.M.; Cettner, A.; Viklander, M.; Walker, L.; Sharp, L.; Westling, E. Overcoming barriers in the transition from piped to alternative drainage systems. In Proceedings of the 2nd International Conference of Sustainability Transitions, Lund University, Lund, Sweden, 13-15 June 2011.

35. Semadeni-Davies, A.; Hernebring, C.; Svensson, G.; Gustafsson, L.-G. The impacts of climate change and urbanisation on drainage in Helsingborg, Sweden: Suburban stormwater. J. Hydrol. 2008, 350, 114-125.

36. Geels, F.W. The hygienic transition from cesspools to sewer systems (1840-1930): The dynamics of regime transformation. Res. Policy 2006, 35, 1069-1082.

37. Cettner, A. Overcoming Inertia to Sustainable Stormwater Management Practice; Luleå University of Technology: Luleå, Sweden, 2012.

38. The International water association, Flood Types. Available online: http://www.iwawaterwiki.org/ xwiki/bin/view/Articles/FloodTypesInundationTypes\#HUrbanFlood (accessed on 13 December 2013).

39. Østerbø Sørumshagen, H.; Bjerkholt, J.T.; Lindholm, O.G. Bærekraftig rehabilitering av vann og avløpsnettet (Sustainable renovation of water- and wastewater system). Vann 2010 3, 357-371.

40. Finans Norge. VASK-vannskaderegisteret (Register of Water Damages). Available online: http://www.fno.no/Hoved/Statistikk/skadeforsikring/VASK (accessed 26 March 2014)

41. Olshammar, M.; Baresel, C. Vattenskador orsakade av baktryck i avloppssystemet —erfarenheteer, regler, hantering och tekniska løsninger (Water damage caused by back pressure in the sewerage system - experiences, rules, management and technical solutions). 2012. Available online: http://www.ivl.se/download/18.5c577972135ee95b56380001184/1362488385940/B2029.pdf (accessed on 13 December 2013).

42. Forsikring og pension. Vejrskader (Weather Damages). Available online: http://www.forsikringogpension.dk/temaer/klima/Documents/skybrudstal\%20sept\%202012.pdf (accessed on 13 December 2013).

43. Lindholm, O.G.; Bjerkholt, J.; Lien, O. Fremmedvann i nordiske avløpsledningsnett (Infiltrated water in Nordic sewer mains). Vann 2012, 1, 39-48.

44. Moberg, S. Senior Legal Advisor Insurance Sweden. Personal Information, 2013.

45. The Danish Government. Lov om afgift av spildevand (Wastewater Tax Act). Available online: https://www.retsinformation.dk/Forms/r0710.aspx?id=13236 (accessed on 13 December 2013).

46. The Swedish Government, Lag om allmänna vattentjänster (Public Water Services Act). Available online: http:/www.notisum.se/rnp/sls/lag/20060412.HTM 2006 (accessed on 13 December 2013).

47. Lindholm, O. Norwegian Institute of Life Sciences, Ås, Norway. Personal Information, 2013.

48. The Danish Government. Lov om vandsektorens organisering og økonomiske forhold (Water Sector Reform Act). Available online: https://www.retsinformation.dk/Forms/ r0710.aspx?id=125346 (accessed on 13 December 2013).

49. Sekse, T. Klimatilpasningstiltak innen vann og avløp $i$ kommunale planer (Climate change adaptation in water and wastewater in municipal plans); Norsk vann BA: Hamar, Norway, 2012. 
50. Naturvårdsverket (Swedish environmental protection agency). Föreskrifter om kontroll av utsläpp till vatten-och markrecipient från anläggningar för behandling av avloppsvatten från tätbebyggelse (Regulations on the control of emissions to water and recipients from treatment plants of urban waste water). In SNFS 1990:14 MS:32; Available online: http://www.naturvardsverket.se/ Documents/foreskrifter/nfs1990/SNFS1990_14k.pdf (accessed on 13 December 2013).

51. Naturvårdsverket (Swedish environmental protection agency) Bräddning från avloppsledningarKontroll av bräddning och bräddningsmängder (Overflow from sewers-inspection of overflow and overflow volumes); Available online: http://www.naturvardsverket.se/Documents/allmrad/ ar_93_6.pdf (accessed on 26 March 2014).

52. Naturstyrelsen (Danish Nature Agency). Punktkilder 2011 (Emission Points 2011). Available online: http://www.naturstyrelsen.dk/NR/rdonlyres/313C43EE-D4D2-4513-9E35-C5740DB435F3/0/ Punktkilderapport2011.pdf (accessed on 26 March 2014).

53. Bull, B. VA-investeringer-Miljøtiltak Som Monner (Water and wastewater investmentsEnvironmental measures that make a difference). Available online: http://www.regjeringen.no/ nb/dokumentarkiv/regjeringen-brundtland-iii/md/Taler-og-artikler-arkivert-individuelt/1996/vainvesteringer_-miljotiltak_som.html?id=261576 (accessed on 26 March 2014).

54. Fylkesmannen i Østfold (County Governor of Østfold). Vedlegg til kommunale utslippstillatelser. Unpublished work, 1992.

55. Fylkesmannen i Østfold (County Governor of Østfold). Vedlegg til kommunale utslippstillatelser (Attachment to municipal emission permits); Fylkesmannen i Østfold Miljøvernavdelingen: Moss, Norway, 2001.

56. Farestveit, T. The Climate and Pollution Agency (KLIF). Personal Information, 2013.

(C) 2014 by the authors; licensee MDPI, Basel, Switzerland. This article is an open access article distributed under the terms and conditions of the Creative Commons Attribution license (http://creativecommons.org/licenses/by/3.0/). 